\title{
Notes on the vocalizations of Black Redstart (Phoenicurus ochruros)
}

Peter Boesman

In the following we briefly analyze and compare voice of the different races of Black Redstart (Phoenicurus ochruros). We also try to quantify the extent of any vocal differences using the criteria proposed by Tobias et al. (2010), as a support for taxonomic review.

We have made use of sound recordings available on-line from Xeno Canto (XC).

Our main interest is to compare voice of races phoenicuroides and rufiventris.

Some examples of song of phoenicuroides:
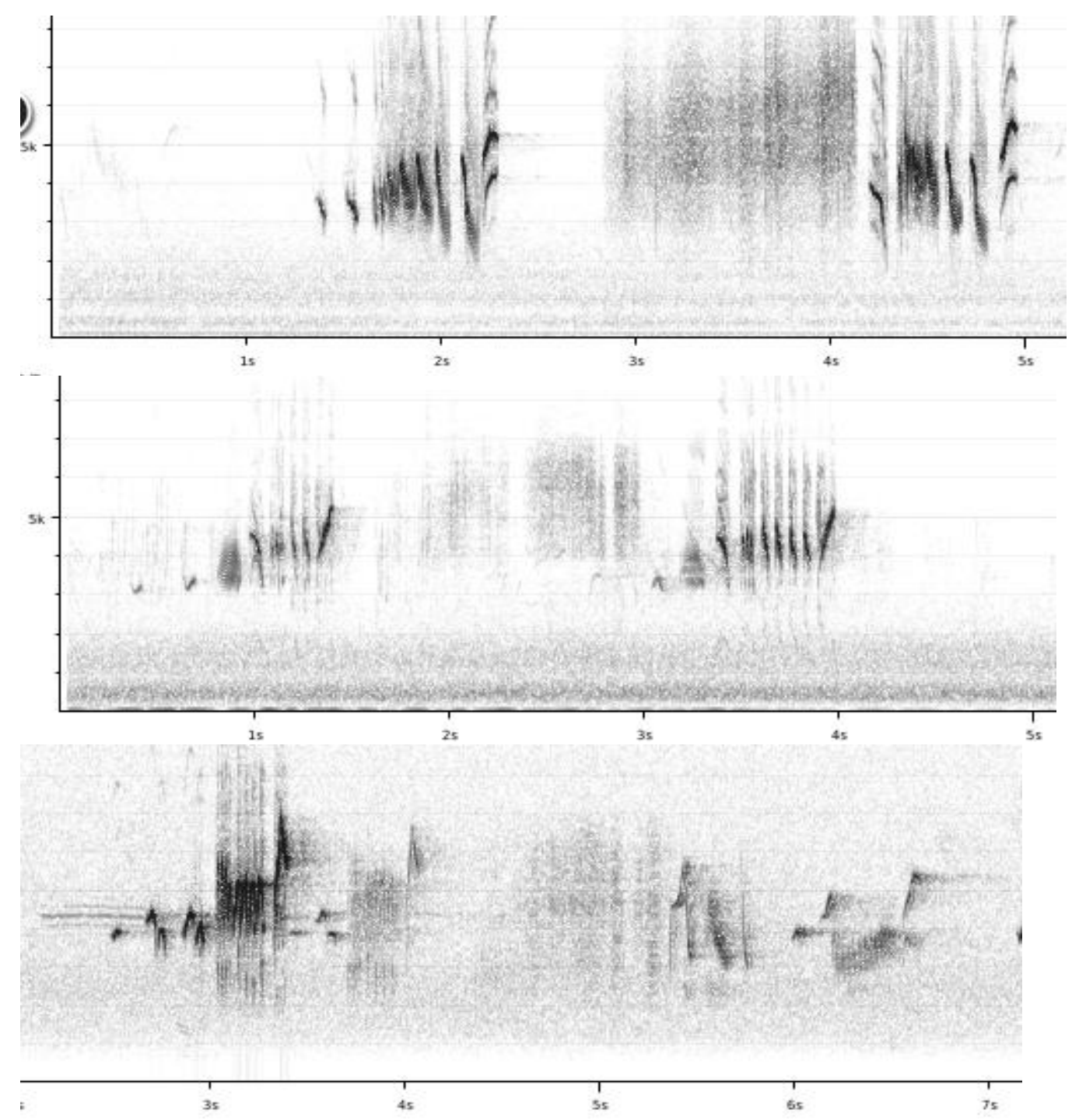


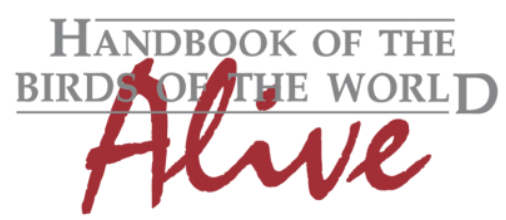

\section{ORNITHOLOGICAL NOTES}

To be compared with (presumed) rufiventris from C China:

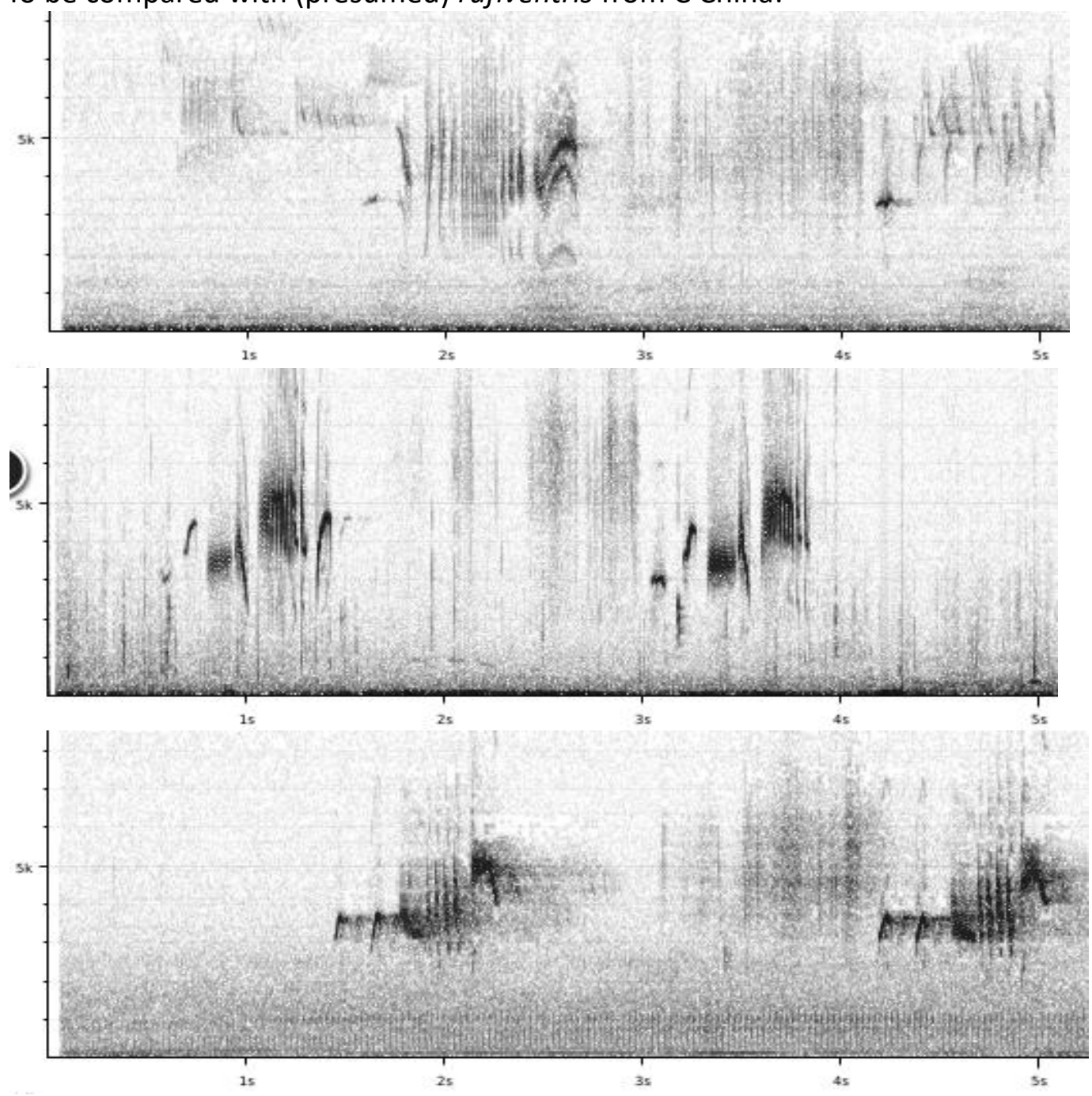

These songs are structurally similar, and given the range of variation in both races, there are no obvious differences based on the few available recordings.

These songs also seem to fit well within the range of variation of western races.

A more detailed analysis (with many more recordings) would be required to find out if there are any consistent vocal differences, but based on present evidence these can be expected to be rather minor.

This note was finalized on 11th May 2016, using sound recordings available on-line at that moment. We would like to thank in particular the many sound recordists who placed their recordings for this species on XC.

\section{References}

Tobias, J.A., Seddon, N., Spottiswoode, C.N., Pilgrim, J.D., Fishpool, L.D.C. \& Collar, N.J. (2010). Quantitative criteria for species delimitation. Ibis 152(4): 724-746. 


\section{Recommended citation}

Boesman, P. (2016). Notes on the vocalizations of Black Redstart (Phoenicurus ochruros). HBW Alive Ornithological Note 330. In: Handbook of the Birds of the World Alive. Lynx Edicions, Barcelona. (retrieved from http://www.hbw.com/node/1252741 on 24 October 2016). 